\title{
Job satisfaction and turnover intention among Iraqi doctors - a descriptive cross-sectional multicentre study
}

Saad Ahmed Ali Jadoo ${ }^{1 *}$, Syed Mohamed Aljunid ${ }^{2}$, Ilker Dastan ${ }^{3}$, Ruqiya Subhi Tawfeeq ${ }^{4}$, Mustafa Ali Mustafa ${ }^{4}$, Kurubaran Ganasegeran ${ }^{5}$ and Sami Abdo Radman AlDubai ${ }^{6}$

\begin{abstract}
Background: During the last two decades, the Iraqi human resources for health was exposed to an unprecedented turnover of trained and experienced medical professionals. This study aimed to explore prominent factors affecting turnover intentions among Iraqi doctors.
\end{abstract}

Methods: A descriptive cross-sectional multicentre study was carried out among 576 doctors across 20 hospitals in Iraq using multistage sampling technique. Participants completed a self-administered questionnaire, which included socio-demographic information, work characteristics, the 10-item Warr-Cook-Wall job satisfaction scale, and one question on turnover intention. Descriptive and bivariate and multiple logistic regression analyses were conducted to identify significant factors affecting turnover intentions.

Results: More than one half of Iraqi doctors (55.2\%) were actively seeking alternative employment. Factors associated with turnover intentions among doctors were low job satisfaction score (odds ratio $(O R)=0.97 ; 95 \%$ confidence interval $(\mathrm{Cl}): 0.95,0.99)$, aged 40 years old or less $(\mathrm{OR}=2.9 ; 95 \% \mathrm{Cl}: 1.74,4.75)$, being male $(\mathrm{OR}=4.2 ; 95 \%$ $\mathrm{Cl}: 2.54,7.03)$, being single $(\mathrm{OR}=5.0 ; 95 \% \mathrm{Cl}: 2.61,9.75)$, being threatened $(\mathrm{OR}=3.5 ; 95 \% \mathrm{Cl}: 1.80,6.69)$, internally displaced $(\mathrm{OR}=3.1 ; 95 \% \mathrm{Cl}: 1.43,6.57)$, having a perception of unsafe medical practice $(\mathrm{OR}=4.1 ; 95 \% \mathrm{Cl}: 1.86,9.21)$, working more than $40 \mathrm{~h}$ per week, $(\mathrm{OR}=2.3 ; 95 \% \mathrm{Cl}: 1.27,4.03)$, disagreement with the way manager handles staff $(\mathrm{OR}=2.2 ; 95 \% \mathrm{Cl}: 1.19,4.03)$, being non-specialist, $(\mathrm{OR}=3.9,95 \% \mathrm{Cl}: 2.08,7.13)$, and being employed in the government sector only ( $\mathrm{OR}=2.0 ; 95 \% \mathrm{Cl}: 1.09,3.82)$.

Conclusion: The high-turnover intention among Iraqi doctors is significantly associated with working and security conditions. An urgent and effective strategy is required to prevent doctors' exodus.

Keywords: Iraqi doctors, Health human resources migration, Turnover intention, Job satisfaction

\section{Background}

The global healthcare sector has been facing major challenges through retention problems and labor shortages [1]. Retention of healthcare workers is a significant concern, because it is extremely costly due to the hiring and training of new workers [2,3]. Besides, labor shortage is detrimental to healthcare system performance and services [4]. According to the World Health Organization

\footnotetext{
* Correspondence: drsaadalezzi@gmail.com

'United Nations University-International Institute of Global Health (UNU-IIGH), International Centre for Case-Mix and Clinical Coding (ITCC), National University of Malaysia Medical Centre (UKMMC), Jalan Yaacob Latiff, 56000 Cheras

Kuala Lumpur, Malaysia

Full list of author information is available at the end of the article
}

(WHO) [5], healthcare labor shortages are common globally; however, this phenomenon is crucial in countries where healthcare performance indicators are the worst. WHO in its report during the Third Global Forum on Human Resources for Health indicated that by 2035 the world will be short of 12.9 million healthcare workers [5].

Causes of labor shortage have been documented in literature. The main causes include prolonged conflicts, political and social instabilities, inadequate investment in healthcare sector, and migration of healthcare workers $[6,7]$. The civil and regional wars jointly with security disturbances in countries such as Lebanon, Somalia, Liberia, Iran, Afghanistan, and other similar nations had 
resulted in a mass exodus and death of the healthcare personnel accompanied with serious health and economic consequences for the population [8-13].

Job dissatisfaction has been stated to be one of the most major and consistent predictor of turnover intention and migration of healthcare workers [1,14-17]. Job satisfaction of healthcare workers arises from relations between experience and work environment and is greatly essential for healthcare workers' motivation [18], retention, and performance [19]. Existing studies confirmed a relationship between the low job satisfaction, the low motivation, and the turnover intention and a relationship between the low job satisfaction and the actual physician migration [20-23]. The concept of turnover intention was broadly studied in items of "conceptualizations, forms, antecedents, consequences, intermediate linkages, mediators, moderators, as well as applications" [24]. However, turnover intention is seldom precisely defined in most of the prominent research outputs [25]. This practice was justified by Bothma [25] to the assumption that people had probably perceived the term to be self-explanatory. Turnover intention was conceptualized by Cotton and Turtle [26] as "an individual's perceived probability of staying or leaving an employing organization". Also, Hom and Griffeth [27] defined turnover intention as" the relative strength of an individual's intent toward voluntary permanent withdrawal from an organization". Tett and Meyer [28] "argued that turnover intention can be used as a valid proxy for actual labor turnover". Several authors viewed turnover intention as "the final step in the decision-making process before a person actually leaves a workplace, in which members actively consider quitting and searching for alternative jobs or professions [28,29]".

Most of the instruments available to measure the turnover intention had used only a limited number of scale items such as the measure based on the Mobley, Horner, and Hollingsworth theory [30]; the scale items were: (1) I think a lot about leaving the organization, (2) I am actively searching for an alternative to the organization, and (3) As soon as it is possible, I will leave the organization. Some other measures are lacking information on the metric properties as in the case of the turnover intention scale (TIS-6) [25]. Therefore, the common trend among various researchers was to use single-item scales [31-33].

The fact that turnover intention was shown to be the strongest predictor of actual leaving or actual turnover among healthcare personnel was documented [34]. Oluwafemi [24] indicated that "the early detection of employee's job dissatisfaction through turnover intention measure would be greatly helpful to resolve the problem of exodus before it exacerbates". Therefore, turnover intention for the purpose of this study implies the Iraqi physicians' intention to potentially quit their present jobs to pursue other alternative employment.

\section{Overview of the Iraqi doctors' situation}

Iraq is an oil-exporting country in the Middle East. It had reached the middle-income status in the 1970s [35,36]. In the period from 1980 to 1988 , healthcare financing was reduced greatly due to the Iran-Iraq War [37]. Throughout the 1990s, a strict ban imposed on the Iraqi regime after the invasion of Kuwait affected the health system in Iraq negatively. The economic collapse, feelings of persecution, job stress, abuses of human rights, and the isolation from the world's scientific environment were the main predictors to leave abroad among Iraqi doctors [38]. Nevertheless, after the US-led invasion of Iraq in 2003, the already weakened health system was exposed to further damage due to organized and widespread acts of looting and destruction $[39,40]$, "accompanied with a systematic targeting of the brightest, most distinguished and most highly regarded doctors and scientists" [41]. Up to date, all available sources about the actual number of physicians who have been kidnapped, assassinated, migrated, and even those who are still working in Iraq are estimated figures [42,43].

Many references [44-48] estimated that around 20,000 Iraqi physicians had fled out since the 2003 invasion. The World Health Organization reported that Iraq is continuing to face a severe shortage of healthcare professionals; it is ranked 95 globally and is in the bottom of the list of the regional countries [49]. To compensate for the continuing brain-drain process in Iraq, the Ministry of Health and Ministry of Higher Education have taken an immediate action after the 2003 invasion to add more medical schools. The number of medical schools rose from just 7 before the 2003 invasion to 12 in 2004 and 20 in 2007 and peaked up to 23 by 2012 [42]. UNESCO's report of 2004 indicated that the total number of medical students in the 12 medical schools was 18 018; this means roughly 2,000 to 3,000 had graduated every year $[42,50]$. Consequently, the physician-to-population ratio showed a slow and sometimes fluctuated growth over the last decade. The World Health Organization, Ministry of Health, and World Bank estimated the ratio of 5.5 per 10,000 populations in 1990, 5.0 in 2002, 6.3 in 2004, 6.6 in 2005, 6.1 in 2006, and 6.9 in $2012[49,51,52]$. However, the national rate of physician per population in 2012 is much lower than the global $(14.2$ per 10,000) and regional rate $(10.9$ per 10,000) and far fewer than neighbouring countries such as Iran (8.9), Kuwait (17.9), Turkey (15.4), Syria (15.0), Saudi Arabia (9.4), and Jordan (24.5) [49]. A special report presented by Webster [48] in 2013 referred to about 24, 745 physicians currently in practice (according to government figures); Iraq's physician-topopulation ratio is about $60 \%$ lower than the average for the other 23 nations in WHO's Eastern Mediterranean Region. Burnham et al. [8] in their findings of 12 tertiary care centres study in Iraq, "they considered the $61 \%$ of 
specialists who left their hospital posts a major loss of human capital from Iraq's hospital sector, a loss that is likely to require some years to fully replace".

The political events and the embargo imposed on Iraq in the 1990s led to a scarcity of research about Iraqi doctors. However, little has been done after the invasion of Iraq in 2003. Al-Khalisi [48] reported that $50 \%$ of doctors surveyed via emails in Iraq showed interest to leave in the near future. The same author reported that $60 \%$ of those who are already abroad had left the country due to security issues. The security breakdown, destruction of infrastructures, workload, bad management, corruption, politicization of the healthcare system, and the lack of strategic planning in all fields were the most notable features in the last decade $[39,40,53]$.

Since June 2014, an escalating rate of violence in central and northern Iraq made medical staff and healthcare facilities a target of repeated and unwarranted military actions [54-56]. It seems that under the full inability of the government over the last decade to save the human resources, the turnover intention among Iraqi doctors became inevitable. Accordingly, our study is very important, relevant, and timely to examine the perceived turnover intention of Iraqi doctors to leave their work or their country and the factors associated with turnover intention, particularly those related to job satisfaction. Thus, by examining predictors of turnover intentions, policy makers in Iraq and in countries with similar conditions may be able to take steps to better retain their healthcare workforce.

\section{Methods}

A cross-sectional study was conducted in Iraq from 1 January until 30 June 2014. A representative sample of doctors was selected by assuming that the turnover intention is 50\% among Iraqi doctors [24] using the following formula:

$$
N=\left[Z \alpha^{2} \times P \times Q /(M . E .)^{2}\right]
$$

So, $n=(1.96)^{2} \times(0.50) \times(0.50) /(0.04)^{2}=600$. Non-response correction $=10 \%$. Thus, the total sample size was 660 . A multistage sampling technique was recruited to collect the data: first, we divided Iraq into five geographical regions (north, central, west, south, and the capital city). Then, we selected one province randomly from each geographical region. Then, two districts from each selected province were selected randomly. Then, from each selected district, two hospitals were selected. Twenty hospitals have been included: five teaching hospitals, five tertiary hospitals, five general hospitals, and five district hospitals. A list of the doctors was obtained from each hospital. An average of 33 doctors per hospital was selected randomly from each hospital, and they were contacted personally by the researcher team. Each eligible respondent received a copy of the questionnaire manually. The contact number of the data collector and his email were provided to each respondent in case they needed any clarification. All the physicians of Iraqi nationality who completed their medical bachelor degree in Iraq, who were employed in the selected hospitals during the study period, and who were willing to participate were included. The chief medical officer (CMO), deputy CMO, hospital manager, and deputy hospital manager were excluded. The total number of doctors who answered the self-administered questionnaire was $576($ response rate $=87.3 \%$ ).

\section{Study instrument}

The self-administered questionnaire used in this study included questions on the socio-demographic information, work characteristics, a 10-item Warr-Cook-Wall (WCW) job satisfaction questionnaire with seven-point Likert scales [57], and one question on turnover intention [30]. All questions were in English because English is the language of teaching and instruction in all Iraqi medical schools and hospitals [58]. The questionnaire was test piloted among 20 doctors.

\section{Dependent variables}

Physicians' turnover intention was assessed by asking the doctors to score one statement "I'm actively seeking alternative employment" adopted from Mobley, Horner, and Hollingsworth [30]. Responses were measured with a fourpoint Likert-type scale ranging from $1=$ "strongly disagree" to $4=$ "strongly agree" and dichotomized into (0) disagreed (original categories 1,2) and (1) agreed (original categories 3,4$)$.

\section{Independent variables}

Job satisfaction was measured with a 10-item job satisfaction scale, which employed a seven-point Likert-type scale ranging from 1 = "very dissatisfied" to 7 = "very satisfied". Cronbach's alpha in our sample was excellent (0.97). We used the total sum score of the 10 items (in range of 10 to 70) to obtain the overall job satisfaction measure. Our predictors included also the socio-demographic factors and work characteristics. Some other predictors were inspired from Iraq's situation which may affect the physician's turnover intention.

The responses were given as either (1) "Yes" or (0) "No" in response to the following questions: "Do you have children?", "Did you lose a family member in Iraq due to violence?", and "Have you been threatened in Iraq to violence?" The "internally displaced" doctor was defined as the doctor who has forced to move from his usual place of residency and work in another place inside the home country, because of armed conflict, generalized violence, 
and human rights violations [59]. The internal displacement was assessed by asking participants, "Have you been displaced internally?" Responses were given as (1) "yes" and (0) "no".

Additionally, the four-point Likert-type scale ranging from $1=$ "strongly disagree" to $4=$ "strongly agree" and dichotomized into (0) disagreed (original categories 1, 2) and (1) agreed (original categories 3,4) was recruited to assess the relationship between doctors and their patients by asking the doctors to score the statement, "The doctor-patient-relationship is excellent"; the safety and security of medical practice in Iraq by asking doctors to score the statement, "Current medical practice in Iraq is safe"; the relationship between doctors and their senior manager was assessed by asking the doctors to score the statement, "The way the senior manager handles the staff is effective"; and the training and educational opportunities was assessed by asking the doctors to score the statement, "The training and educational opportunities in your interest area were good".

Furthermore, the working hours per week were defined and categorized as (1) "40 hours per week" and (0) "more than 40 hours per week". Number of years spent at their work or the same facility was categorized as (0) less than 10 years and (1) being 10 years and more. The current professional level was defined as whether the doctor has completed at least one of the postgraduate degrees (diploma, master, doctorate) or has only the bachelor of medicine and surgery and categorized as (1) specialist and (0) non-specialist. Type of employment was defined and categorized as (1) when the doctor was employed in "the government only" and (0) "mixed" when the doctor was employed in the government and also worked in the private sector.

\section{Ethical considerations}

Our study protocol was approved by the Izmir Economic University's Ethics Committee in 2014, Code number (B.30.2.IEU.0.05.05-020-014) and by respective authorities of the selected hospitals where data collection took place. Confidentiality was assured and written consent was obtained from all respondents.

\section{Data analysis}

Data collected were analysed using Statistical Package for Social Science (SPSS) program version 20.0 (SPSS Inc., Chicago IL, USA) [60]. Normality tests were done, and all the quantitative data were found to be normally distributed. Frequency distribution and descriptive statistics of socio-demographic variables and work characteristics were obtained to provide the sample profile. Furthermore, a descriptive analysis was performed concerning the overall job satisfaction and the 10 items of job satisfaction to obtain the means and standard deviation (SD). An independent- sample $t$-test was run to determine if there were differences in overall job satisfaction between doctors who were actively seeking alternative employment (turnover intentions) and those who were not. Chi square tests were used in the bivariate analysis for binary or categorical variables. Significant factors predicting turnover intention on bivariate analysis ( $p$ value $<0.05$ ) were included in the multivariate model. Multiple logistic regression analysis (Enter technique) was performed to identify significant predictors of turnover intentions. In "Enter technique", the variables in the models which are not significant are removed one by one until a satisfactory model is obtained. Odds ratio and 95\% confidence interval were calculated. An alpha level of $p<0.05$ is considered to be statistically significant.

\section{Results}

Descriptive and general characteristics of related factors

Five hundred and seventy-six completed questionnaires were analysed. Mean age $( \pm$ SD) was 40.43 years $( \pm 8.59)$, and the age ranged from 27 to 56 years old. Two thirds of doctors were married (64.2\%), and 53.8\% were females (and 51.2\% had children). Out of the total sample, 26.6\% reported they had lost one or more of their close relatives in Iraq due to violence, $54.3 \%$ of them have been threatened, and $39.1 \%$ have been internally displaced at least once because of violence. Two thirds $(66.8 \%)$ of the doctors were from the urban region, and the majority (59.5\%) had spent more than 10 years at their work or the same facility. Out of the 576 doctors, 255 (44.3\%) were employed in the government sector only, 39.8\% were specialists, and $46.4 \%$ worked more than $40 \mathrm{~h}$ per week. Four hundred and seven (70.7\%) of the doctors reported that their relation with the patients was excellent, and $385(66.8 \%)$ of them considered their medical practice in Iraq was unsafe or risky. Forty percent disagreed with the way their senior manager handled staff, and $45.1 \%$ were dissatisfied with their training and educational opportunities (Table 1).

\section{Job satisfaction and turnover intention}

The mean (SD) value on the total job satisfaction score was 42.44 $(\mathrm{SD}=14.87)$. The level of satisfaction on "the freedom to choose own method of working" was the highest followed by opportunities to use their abilities, remuneration, working hours, and variation in work. The lowest satisfaction score was reported for physical working conditions, recognition for good work, overall job satisfaction, amount of responsibility, and the cooperation with colleagues and fellow workers (Table 2).

An independent-sample $t$-test was run to determine if there were differences in overall job satisfaction between doctors who were actively seeking alternative employment (turnover intention) and their counterparts. There were no outliers in the data, as assessed by inspection of 
Table 1 Respondents' socio demographic and work characteristics $(n=576)$

\begin{tabular}{|c|c|c|c|}
\hline Respondent's characteristics & Category & $N$ & $\%$ \\
\hline \multirow[t]{2}{*}{$\overline{\text { Age }}$} & $\leq 40$ years old & 285 & 49.5 \\
\hline & $>40$ years old & 291 & 50.5 \\
\hline \multirow[t]{2}{*}{ Gender } & Male & 266 & 46.2 \\
\hline & Female & 310 & 53.8 \\
\hline \multirow[t]{2}{*}{ Marital status } & Married & 370 & 64.2 \\
\hline & Single & 206 & 35.8 \\
\hline \multirow[t]{2}{*}{ Presence of children } & Yes & 295 & 51.2 \\
\hline & No & 281 & 48.8 \\
\hline \multirow[t]{2}{*}{ Residency } & Rural & 211 & 36.6 \\
\hline & Urban & 365 & 63.4 \\
\hline \multirow[t]{2}{*}{ Loss of family member } & Yes & 153 & 26.6 \\
\hline & No & 423 & 73.4 \\
\hline \multirow[t]{2}{*}{ Exposure to threat } & Yes & 313 & 54.3 \\
\hline & No & 263 & 45.7 \\
\hline \multirow[t]{2}{*}{ Internally displaced doctors } & Yes & 225 & 39.1 \\
\hline & No & 351 & 60.9 \\
\hline \multirow[t]{2}{*}{ Medical practice in Iraq is safe } & Agree & 191 & 33.2 \\
\hline & Disagree & 385 & 66.8 \\
\hline \multirow[t]{2}{*}{ The current professional level } & Specialist & 229 & 39.8 \\
\hline & Non-specialist & 347 & 60.2 \\
\hline \multirow{2}{*}{$\begin{array}{l}\text { The way managers handle } \\
\text { staff was effective }\end{array}$} & Agree & 343 & 59.5 \\
\hline & Disagree & 233 & 40.5 \\
\hline \multirow{2}{*}{$\begin{array}{l}\text { Doctor-patient relationship } \\
\text { is excellent }\end{array}$} & Agree & 169 & 29.3 \\
\hline & Disagree & 407 & 70.7 \\
\hline \multirow[t]{2}{*}{ Duration of work } & $<$ or $=10$ years & 154 & 26.7 \\
\hline & $>10$ years & 422 & 73.3 \\
\hline \multirow{2}{*}{$\begin{array}{l}\text { Training and educational } \\
\text { opportunities }\end{array}$} & Satisfied & 316 & 54.9 \\
\hline & Dissatisfied & 260 & 45.1 \\
\hline \multirow[t]{2}{*}{ Hours of work/week } & $>40 \mathrm{~h}$ & 267 & 46.4 \\
\hline & $40 \mathrm{~h}$ & 309 & 53.6 \\
\hline \multirow[t]{2}{*}{ Type of employment } & Government only & 255 & 44.3 \\
\hline & $\begin{array}{l}\text { Government and } \\
\text { private }\end{array}$ & 321 & 55.7 \\
\hline
\end{tabular}

a boxplot. Overall job satisfaction scores for each level of turnover intention were normally distributed, as assessed by the Kolmogorov-Smirnov test $(p>0.05)$. Overall job satisfaction was more among doctors who were not actively seeking alternative employment $(m=49.38$, $\mathrm{SD}=12.52$ ) than doctors who were actively seeking alternative employment $(m=36.80, \mathrm{SD}=14.25)$, a statistically significant difference $(m=12.58,95 \%$ CI $(10.39$, $14.77), t(570.385)=11.269, p<0.001)$. More than one half of the doctors $(318,55.2 \%)$ agreed that they were actively seeking alternative employment compared to (250, 44.8\%) who disagreed.
Table 2 Descriptive statistics of the 10 items and overall job satisfaction scale

\begin{tabular}{llllll}
\hline No. & Job satisfaction statements (WCW) & Mean & SD & Min. & Max. \\
\hline 1 & Physical working conditions & 3.81 & 1.63 & 1 & 7 \\
2 & $\begin{array}{l}\text { Freedom to choose your own method } \\
\text { of working }\end{array}$ & 4.60 & 1.79 & 1 & 7 \\
3 & $\begin{array}{l}\text { Your colleagues and fellow workers } \\
4\end{array}$ & 4.26 & 1.61 & 1 & 7 \\
5 & Recognition you get for good work & 3.89 & 1.62 & 1 & 7 \\
6 & Your remuneration, i.e. income & 4.40 & 1.70 & 1 & 7 \\
7 & Opportunity to use your abilities & 4.54 & 1.69 & 1 & 7 \\
8 & Your hours of work & 4.30 & 1.75 & 1 & 7 \\
9 & Amount of variety in your job & 4.30 & 1.72 & 1 & 7 \\
10 & $\begin{array}{l}\text { Taking everything into consideration, } \\
\text { how do you feel about your job? }\end{array}$ & 4.12 & 1.79 & 1 & 7 \\
11 & Overall scale job satisfaction & 42.44 & 14.87 & 10 & 70 \\
\hline
\end{tabular}

WCW, Warr-Cook-Wall job satisfaction scale.

Factors associated with turnover intention in bivariate analysis

Cross tabulation indicated that only doctors who were aged 40 years old or less, (chi square test $\left(\chi^{2}\right)=63.79, p<0.001$ ), being male $\left(\chi^{2}=41.10, p<0.001\right)$, being single (unmarried, divorced, and widowed) $\left(\chi^{2}=26.18, p<0.001\right)$, being threatened $\left(\chi^{2}=11.54, p=0.001\right)$, internally displaced $\left(\chi^{2}=31.69, p<0.001\right)$, perceived work unsafe or risky, $\left(\chi^{2}=4.91, p=0.027\right)$, and being non-specialist $\left(\chi^{2}=\right.$ 80.57, $p<0.001)$, disagreed with the way the manager handles the staff $\left(\chi^{2}=71.02, p<0.001\right)$, employed in the government sector only $\left(\chi^{2}=50.72, p<0.001\right)$, and working more than $40 \mathrm{~h}$ per week $\left(\chi^{2}=61.29, p<0.001\right)$ were significantly associated with the turnover intention (Table 3).

\section{Factors associated with turnover intention in multiple logistic regression}

Table 4 presents the final model of the multivariable logistic regressions. Overall job satisfaction (odds ratio $(\mathrm{OR})=0.97,95 \% \mathrm{CI}: 0.95$ to 0.99$)$ with the other 10 variables was associated significantly with "turnover intention" $(p<0.05)$. The doctors who disagreed with the way managers handle the staff $(\mathrm{OR}=2.19,95 \% \mathrm{CI}$ : 1.19 to 4.03$)$ and working more than $40 \mathrm{~h}$ per week $(\mathrm{OR}=2.26,95 \% \mathrm{CI}: 1.27$ to 4.03$)$ had the lowest odds ratios. While the doctors who are single $(\mathrm{OR}=5.05,95 \%$ CI: 2.61 to 9.75$)$ and being male $(\mathrm{OR}=4.23,95 \% \mathrm{CI}: 2.54$ to 7.03 ) had the highest odds ratios. The Hosmer and Lemeshow test indicated a good fit $(p=0.320)$. The total model was significant $(p=0.001)$ and accounted for $58.4 \%$ of variance (Nagelkerke $R$ square $=0.584$ ). 
Table 3 Bivariate analysis of predictors in turnover intention

\begin{tabular}{|c|c|c|c|c|c|}
\hline \multirow[t]{2}{*}{ Factors } & \multirow[t]{2}{*}{ Category } & \multirow{2}{*}{$\begin{array}{l}\text { Yes } \\
318(55.2 \%)\end{array}$} & \multirow{2}{*}{$\begin{array}{l}\text { No } \\
250(44.8 \%)\end{array}$} & \multirow[t]{2}{*}{$x^{2}$} & \multirow[t]{2}{*}{$p$} \\
\hline & & & & & \\
\hline \multirow[t]{2}{*}{ Age } & $\leq 40$ years & 205(71.9) & $80(28.1)$ & 63.79 & $<0.001$ \\
\hline & $>40$ years & 113(38.8) & 178(61.2) & & \\
\hline \multirow[t]{2}{*}{ Gender } & Male & 185(69.5) & $81(30.5)$ & 41.10 & $<0.001$ \\
\hline & Female & 133(42.9) & $177(57.1)$ & & \\
\hline \multirow[t]{2}{*}{ Marital status } & Single & 143(69.4) & 63(30.6) & 26.18 & $<0.001$ \\
\hline & Married & 175(47.3) & $195(52.5)$ & & \\
\hline \multirow[t]{2}{*}{ Presence of children } & Yes & 161(54.6) & 134(45.4) & 0.10 & 0.755 \\
\hline & No & 157(55.9) & 124(44.1) & & \\
\hline \multirow[t]{2}{*}{ Residency } & Rural & $117(55.5)$ & $94(44.5)$ & 0.008 & 0.929 \\
\hline & Urban & $201(55.1)$ & 164(44.9) & & \\
\hline \multirow[t]{2}{*}{ Loss of family member } & Yes & $91(59.5)$ & $62(40.5)$ & 1.54 & 0.215 \\
\hline & No & 227(53.7) & 196(46.3) & & \\
\hline \multirow[t]{2}{*}{ Being threatened } & Yes & 193(55.2) & $120(44.8)$ & 11.54 & 0.001 \\
\hline & No & $125(47.5)$ & $138(52.5)$ & & \\
\hline \multirow[t]{2}{*}{ Displaced internally } & Yes & 157(69.8) & $68(30.2)$ & 31.69 & $<0.001$ \\
\hline & No & 161(45.9) & 190(54.1) & & \\
\hline \multirow[t]{2}{*}{ Medical practice is safe } & Disagree & $225(58.4)$ & 160(41.6) & 4.91 & 0.027 \\
\hline & Agree & $93(48.7)$ & $98(51.3)$ & & \\
\hline \multirow[t]{2}{*}{ Hours of work/week } & $>40$ Hours & 194(72.7) & $73(27.3)$ & 61.30 & $<0.001$ \\
\hline & $\leq 40$ Hours & 124(40.1) & 185(59.9) & & \\
\hline \multirow[t]{2}{*}{ Way manager handles staff } & Disagree & 178(76.4) & $55(23.6)$ & 71.02 & $<0.001$ \\
\hline & Agree & $140(40.8)$ & 203(59.2) & & \\
\hline \multirow[t]{2}{*}{ Doctor-patient relationship } & Agree & $90(53.3)$ & $79(46.7)$ & 0.37 & 0.543 \\
\hline & Disagree & $228(56.0)$ & 179(44.0) & & \\
\hline \multirow[t]{2}{*}{ The professional level } & Non specialist & 244(70.3) & 103(29.7) & 80.57 & $<0.001$ \\
\hline & Specialist & 74(32.3) & 155(67.7) & & \\
\hline \multirow[t]{2}{*}{ Duration of work } & $\leq 10$ Years & $93(60.4)$ & $61(39.6)$ & 0.10 & 0.748 \\
\hline & $>10$ Years & $225(53.3)$ & 197(46.7) & & \\
\hline \multirow[t]{2}{*}{ Training opportunities } & Satisfied & 170(53.8) & $146(46.2)$ & 0.56 & 0.453 \\
\hline & Dissatisfied & 148(56.9) & 112(43.1) & & \\
\hline \multirow[t]{2}{*}{ Employment } & Government only & 183(71.8) & $72(28.2)$ & 50.72 & $<0.001$ \\
\hline & Mixed & 135(42.1) & 186(57.9) & & \\
\hline \multirow[t]{3}{*}{ Over all job satisfaction } & & Mean & SD & & \\
\hline & With intention & 36.80 & 14.25 & & \\
\hline & Without intention & 49.38 & 12.52 & & \\
\hline
\end{tabular}

$p<0.05$ is statistically significant for data in italics.

\section{Discussion}

In the last decades, developing countries have seen healthcare professionals leaving the profession or migrating to developed countries [61]. This pattern is a particular problem in Iraq where the healthcare system has faced a catastrophic collapse since 1991. Iraqi doctors left the country due to falling wages during the sanction years, between 1990 and 2003, and because of the worsening security conditions after the 2003 invasion [62]. Even though the migration rates have slowed more recently, it was estimated that about half of the doctors have already left Iraq after the 2003 invasion, and most healthcare providers have significant turnover intentions or to leave the country [46]. It has been documented 
Table 4 Factors associated with turnover intention in multiple logistic regression

\begin{tabular}{|c|c|c|c|c|c|c|}
\hline Variables & $B$ & SE & Wald & $p$ value & OR & $95 \% \mathrm{Cl}$ \\
\hline Overall job satisfaction & -0.033 & 0.012 & 8.01 & 0.004 & 0.97 & $0.95-0.99$ \\
\hline 40 years old or less & 1.056 & 0.256 & 16.97 & 0.000 & 2.87 & $1.74-4.75$ \\
\hline More than 40 years old & & & & & Reference & \\
\hline Male & 1.441 & 0.259 & 30.90 & 0.000 & 4.23 & $2.54-7.03$ \\
\hline Female & & & & & Reference & \\
\hline Single & 1.619 & 0.336 & 23.23 & 0.000 & 5.05 & $2.61-9.75$ \\
\hline Married & & & & & Reference & \\
\hline Being threatened & 1.243 & 0.335 & 13.78 & 0.000 & 3.47 & $1.80-6.69$ \\
\hline Not threatened & & & & & Reference & \\
\hline Internally displaced & 1.118 & 0.390 & 8.22 & 0.004 & 3.06 & $1.43-6.57$ \\
\hline No & & & & & Reference & \\
\hline Unsafe medical practice & 1.420 & 0.408 & 12.09 & 0.001 & 4.12 & $1.86-9.21$ \\
\hline Safe & & & & & Reference & \\
\hline$>40 \mathrm{~h} /$ week & 0.822 & 0.296 & 7.71 & 0.005 & 2.28 & $1.27-4.06$ \\
\hline$<$ or $=40 \mathrm{~h} /$ week & & & & & Reference & \\
\hline $\begin{array}{l}\text { Disagreement with the way managers } \\
\text { handle staff }\end{array}$ & 0.785 & 0.310 & 6.39 & 0.011 & 2.19 & $1.19-4.03$ \\
\hline Agree & & & & & Reference & \\
\hline Non-specialist & 1.349 & 0.314 & 18.50 & 0.000 & 3.85 & $2.08-7.13$ \\
\hline Specialist & & & & & Reference & \\
\hline Employed in government only & 0.712 & 0.321 & 4.931 & 0.026 & 2.04 & $1.09-3.82$ \\
\hline Mixed & & & & & Reference & \\
\hline Constant & -3.719 & 0.811 & 21.01 & 0.000 & 0.024 & \\
\hline
\end{tabular}

OR, odds ratio.

that the strongest predictor of an actual departure is developing an intention to leave the job [34]. An effective strategy for dealing with this crisis would be to identify health professionals' turnover intention and take steps to reverse this intention. Due to the length of time need to train new physicians, it is important to retain existing ones in order to avoid serious public consequences $[2,3,34]$.

In this study, more than half of the doctors surveyed (55\%) were actively seeking alternative employment (turnover intention). Various factors related to this intention were examined. Findings revealed significant associations between turnover intention and job satisfaction, violence, and a number of demographic variables of age, gender, marital status, and a number of work-related variables of positional tenure, working hours, internal displacement, unsafe practice, managerial efficiency, and hospital type.

In this study, job satisfaction was negatively associated with turnover intention. The findings are similar to other studies done in Saudi Arabia [21], Lebanon [22], Ghana [33], Palestine [63], Pakistan [64], and China [65]. It is essential that policy makers and healthcare managers gain a better understanding of the causes of job dissatisfaction in the medical profession in order to develop effective retention strategies.

In this study, more than half of all healthcare professionals (54\%) felt threatened, and $67 \%$ believed that the conditions of their medical practice were not sufficiently safe. The perception of being threatened and unsafe workplace due to violence are important predictors of turnover intention among the health professionals. Heponiemi et al. [66] found that the highest levels of turnover intentions were among physicians who had encountered a workplace physical violence. Additionally, reduced job satisfaction and a decline in the quality of job performance were reported among male junior physicians who were facing verbal and physical abuse from patients or their caretakers, respectively [67].

In Iraq, insecurity has been an important driver for external and internal migration of health professionals $[8,48]$. Burnham et al. [8] estimated that violent event rates associated with the migration of doctors have been increasing; migrations from Iraq were greatest in 2006, a time of remarkably intense violence, and the number of specialists at Baghdad hospitals declined by $24 \%$ between 2004 and 2007. To retain the existing healthcare workforce in Iraq, 
the results of this study clearly suggest that more attention should be paid to prevailing violence and increasing the security associated with the workplace [23].

In this study, age, gender, and marital status were associated with turnover intention among Iraqi doctors. Younger physicians were more likely to indicate a turnover intention compared to older doctors. This corresponds well with previous findings among physicians and other healthcare providers $[13,21,22,66,65,68]$. Older doctors may have stronger personal ties and may be more satisfied with their work and, therefore, less likely to contemplate leaving $[13,21,68]$.

The literature is not consistent in terms of the relationship between gender and doctors' turnover intention. However, this study showed that males had higher levels of turnover intention compared to females. This finding could be due to cultural issues such as the traditional gender roles, which attribute achievement and adventurousness of males. These opportunities are culturally less available for females with families who are usually less mobile and are less able to migrate or to quit their job $[22,23,65,69]$. Previous studies reported similar results among male physicians and nurses to have higher likelihood of turnover intentions compared to their female counterparts in China and Lebanon respectively [65,22].

Another significant predictor of turnover intention is marital status; unmarried doctors were more likely to indicate turnover intention. Similar findings were reported by Tai et al. [70] and El-Jardali et al. [22]. This finding could be explained by the fact that single healthcare professionals generally have fewer family responsibilities, thus making them more mobile. Moreover, work-related issues may be further affecting doctors' turnover intention. The WHO reported that poor working conditions affect the level of satisfaction and retention [71]. Another finding of this study showed that doctors who are working more than $40 \mathrm{~h}$ per week were more likely to have turnover intention. Similarly, Heponiemi et al. [72] pointed out that physicians in Finnish "who had been on active call more than 40 hours per month had more turnover intentions than the other physicians". Also Malik et al. [73] found that the doctors in Pakistan could be more satisfied with their jobs and have less intentions to leave their jobs when able to manage their work and life activities.

This study showed that internal displacement was positively associated with turnover intention. Around $40 \%$ of the participants were forced to move from their usual place of residency to work in far places within the country. Morton and Burnham [74] reported that such moves would be negatively related to job satisfaction and positively related to job stress and turnover intention. This study found that non-specialist doctors and those who considered their senior managers ineffective are more likely to have commitment issues or turnover intention than others. Similarly, Ahmad and Riaz [64] found a positive correlation between the attitudes of an immediate boss and the turnover intention of a subordinate. They argued that "the autocratic management style had negative relationship with intent to stay". Koelewijn et al. [75] also indicated that physicians who perceive a high level of bureaucracy and lacking of influence on hospital policy are more likely to entertain dissatisfaction with management style. Furthermore, we found that physicians who are working in the public sector reported high-turnover intention compared to those having dual employment. Boerjan et al. [76] indicated that a double load created by working in a highly demanding job and being an apprentice in this profession at the same time may further exacerbate junior doctors' intention to leave. Therefore, supporting new hires and non-specialist doctors in their healthcare roles may help decrease their turnover intention, particularly in public hospitals which are usually under-resourced and yet serve the poorer population in majority [77].

\section{Limitations of study}

There are some limitations to this study. First, we analysed measured intentions to leave rather than actual turnovers, but actual behavioural measures of the Iraqi doctors may be different from intentional measures. Further, response bias is a possible bias, because we had no information about the non-respondents and if they differed in some criteria from the respondents. This study is also limited by the security situation in the country which affected the accessibility to the hospitals and districts. Many doctors preferred to complete the questionnaire in the privacy of their own home rather than at the hospital. Ethnic and sectarian conflict in Iraq peaked in 2006 and has had a major role in the migration and displacement of a large number of doctors; however, we omitted ethnic and religious affiliations from the questionnaire due to the sensitivity of these issues. Although we have test piloted the English version of the questionnaire, the language barrier could be a limitation because the native language of the respondent is Arabic. Finally, the study is a cross-sectional study which cannot establish a causal relationship between the variables.

\section{Policy implication}

Healthcare workers' turnover intention and migration are major problems facing the health industry, especially in countries suffering from prolonged war and civil conflicts coupled with political and economic decline like Iraq. We recommend providing effective regulations to protect healthcare staff from violent actions. The Iraqi government is now reviewing a policy of not issuing certificates to medical students for the duration of postgraduate training and practising to prevent their migration for few years. 
However, we believe that such a procedure should be accompanied with comprehensive reforms such as standardizing medical practices and medical procedure costs for the public and private sectors, improving working conditions, reducing the workload, offering competitive wages and benefit packages, and introducing new payment mechanisms such as pay for performance or casemix and diagnosis-related group systems. Moreover, the building up of non-monetary incentives is necessary to attract doctors by reducing the problems caused by work-related issues. We suggest that healthcare management should recognize and reward doctors who stay longer. Supervisor support programmes should be improved. It is recommended that healthcare managers should consider the current employee assistance programmes and to improve professional hospital administration. Administrators could provide career ladders, communication, and training programmes to make hospital and clinic environment more attractive, especially to the high-turnover-prone group of younger, non-specialist, and less tenured doctors. The above recommended actions may help to improve the retention of doctors working in public hospitals.

\section{Conclusion}

It is concluded that intention to leave among Iraqi doctors was high, and it was significantly associated with job dissatisfaction and feeling unsecured, working conditions, and socio-demographic factor conditions. More than one half of the participants were actively seeking alternative employment. The results may be useful for policy makers and health administrators wishing to stop more doctors' exodus or to retain the existing healthcare professionals in Iraq. To achieve this, urgent and concrete strategies must be developed focusing on the job security and job factors related to satisfaction. A particular attention should be given to the younger and single doctors. Improving working conditions, reducing work load, creating a safer working environment, and training senior managers to support their healthcare staff are very important actions. It is important to give particular attention to those who had high risk of turnover intention, e.g. young, single, and male, and those with less tenure, and those who worked at the public healthcare sector. This can be achieved by improving motivation and commitment through offering competitive wages, providing intrinsic rewards related to work schedule and conditions, and non-monetary support, such as training and supervision.

\footnotetext{
Abbreviations

CMO: Chief medical officer; WCW: Warr-Cook-Wall; WHO: World Health Organization; TIS-6: Turnover intention scale; Cl: Confidence interval; $X^{2}$ : Chi square test; OR: Odds ratio; SD: Standard deviation; $n$ : Number of all respondents; $B$ : Unstandardized coefficients; SE: Standard error; $p$ value: Level of significance.
}

\section{Competing interests}

The authors declare that they have no competing interests.

\section{Authors' contributions}

SAAJ conceived study; collected, coded, and analysed the data; and wrote the first and final draft of the article. SMJ advised and contributed to the study design and data analysis. ID advised and contributed to the data analysis and writing of the article. RST advised and contributed to the study design and writing of the first draft. MAM contributed to the data collection and advised and participated in the study design and writing of the first draft. KG and SARA contributed in study design, data analysis and interpretation, and preparation and editing of the manuscript. All authors have contributed to and approved the final manuscript.

\section{Acknowledgements}

We are grateful first to all the Iraqi doctors for their working every day to serve their public in the face of violence and second for the participants for their time and openness during the data collection. Special thanks to all the teams that participated in collecting the data particularly the Iraqi Red Crescent of Tiqrit city. We would also like to acknowledge the chief medical officer (CMO), deputy CMO, hospital manager, and deputy hospital manager for their support and unlimited cooperation.

\section{Author details}

${ }^{1}$ United Nations University-International Institute of Global Health (UNU-\|GH), International Centre for Case-Mix and Clinical Coding (ITCC), National University of Malaysia Medical Centre (UKMMC), Jalan Yaacob Latiff, 56000 Cheras Kuala Lumpur, Malaysia. ${ }^{2}$ International Centre for Case-Mix and Clinical Coding (ITCC), National University of Malaysia Medical Centre (UKMMC) Jalan Yaacob Latiff, 56000 Cheras Kuala Lumpur, Malaysia. ${ }^{3}$ Department of Economics, Izmir University of Economics, Izmir, Turkey. ${ }^{4}$ Department of Public Health, Faculty of Medicine, Tiqrit University, Tiqrit, Iraq. ${ }^{5}$ Medical Department, Tengku Ampuan Rahimah Hospital (HTAR), Jalan Langat, Klang, Selangor, Malaysia. 'Department of Community Medicine, International Medical University (IMU), Bukit Jalil, Kuala Lumpur, Malaysia.

Received: 12 January 2015 Accepted: 9 April 2015

Published online: 19 April 2015

\section{References}

1. Steinmetz S, de Vries DH, Tijdens KG. Should I stay or should I go? The impact of working time and wages on retention in the health workforce. Hum Resour Health. 2014;12:23. http://dx.doi.org/10.1186/1478-4491-12-23.

2. Waldman JD, Kelly F, Sanjeev A, Smith $H$. The shocking cost of turnover in health care. Health Care Manage Rev. 2004;29(1):2-7.

3. Cohen A, Golan R. Predicting absenteeism and turnover intentions by past absenteeism and work attitudes: an empirical examination of female employees in long term nursing care facilities. Career Dev Int. 2007;12:416-32. http://dx.doi.org/10.1108/13620430710773745

4. Coomber B, Barriball KL. Impact of job satisfaction components on intent to leave and turnover for hospital-based nurses: a review of the research literature. Int J Nurs Stud. 2007:44:297-314. http://dx.doi.org/10.1016/ j.ijnurstu.2006.02.004

5. World Health Organization. Global health workforce shortage to reach 12.9 million in coming decades; 2013. Available on: http://www.who.int/ mediacentre/news/releases/2013/health-workforce-shortage/en/.

6. Dayrit MM, Dolea C, Dreesch N. Addressing the HRH crisis in countries: how far have we gone? What can we expect to achieve by 2015? Rev Peru Med Exp Salud Publica. 2011;28:327-36.

7. Willis-Shattuck M, Bidwell P, Thomas S, Wyness L, Blaauw D, Ditlopo P. Motivation and retention of health workers in developing countries: a systematic review. BMC Health Serv Res. 2008;8:247. http://dx.doi.org/ 10.1186/1472-6963-8-247

8. Burnham G, Lafta R, Doocy S. Doctors leaving 12 tertiary hospitals in Iraq 2004-2007. Soc Sci Med. 2009;69:172-7. http://dx.doi.org/10.1016/ j.socscimed.2009.05.021.

9. Kronfol NM, Sibai AM, Rafeh N. The impact of civil disturbances on the migration of physicians: the case of Lebanon. Med Care. 1992;30:208-15.

10. Leather A, Ishmael EA, Abdi YA, Abbey MH, Gulaid SA, Walhad SA, et al. Working together to rebuild health care in post-conflict Somaliland. Lancet. 2006;368(9541):1119-25. 
11. United Nations Development Programme, Ministry of Planning and Economic Affairs, Government of Liberia. National human development report Liberia 2006. Monrovia: Government of Liberia; 2006. Available on: http://planipolis.iiep.unesco.org/upload/Liberia/Liberia\%20HDR.pdf.

12. Willis EA, Taghipour J. Effects of prolonged war and repression on a country's health status and medical services: some evidence from Iran 1979-90. Med War. 1992:8:185-99.

13. Fogarty L, Kim YM, Juon H-S, Tappis H, Noh JW, Zainullah $\mathrm{P}$, et al. Job satisfaction and retention of health-care providers in Afghanistan and Malawi. Hum Resour Health. 2014;12:11. http://dx.doi.org/10.1186/1478-4491-12-11.

14. David HP, Chakraborty S, Mahapatra P, Steinhardt L. Job satisfaction and motivation of health workers in public and private sectors: cross-sectional analysis from two Indian states. Hum Resour Health. 2010;8:27. http:// dx.doi.org/10.1186/1478-4491-8-27.

15. Samad S. The contribution of demographic variables: job characteristics and job satisfaction on turnover intentions. JIMS. 2006;1(1):128-37.

16. Hellman CM. Job satisfaction and intent to leave. J Soc Psychol. 1997;137:677-89. http://dx.doi.org/10.1080/00224549709595491.

17. Ojakaa D, Olango S, Jarvis J. Factors affecting motivation and retention of primary health care workers in three disparate regions in Kenya. Hum Resour Health. 2014:12:33. 1. http://www.human-resources-health.com/content/12/1/33.

18. Mowday RT. Strategies for adapting to high rate of employee turnover. Hum Resour Manage. 1984;23(4):365-80. http://dx.doi.org/10.1002/ hrm.3930230404.

19. Kivimaki M, Voutilainen $\mathrm{P}$, Koskinen $\mathrm{P}$. Job enrichment, work motivation, and job satisfaction in hospital wards: testing the job characteristics model. J Nurs Manag. 1995;3:87-91. http://dx.doi.org/10.1111/j.1365-2834.1995.tb00086.x.

20. Ojedokun AO. Perceived job insecurity, job satisfaction and intention to quit. Afr J Psychol Study Soc Issue. 2008;11(2):204-20.

21. Alasmari HAM, Douglas C. Job satisfaction and intention to leave among critical care nurses in Saudi Arabia. Middle East J Nurs. 2011;6(4):3-12.

22. El-Jardali F, Dimassi H, Dumit N, Jamal D, Mouro G. A national crosssectional study on nurses' intent to leave and job satisfaction in Lebanon: implications for policy and practice. BMC Nurs. 2009:8:3.

23. Alameddine M, Saleh S, El-Jardali F, Dimassi H, Mourad Y. The retention of health human resources in primary healthcare centers in Lebanon: a national survey. BMC Health Serv Res. 2012;12:419.

24. Oluwafemi OJ. Predictors of turnover intention among employees in Nigeria's oil industry. Organ Mark Emerg Econ. 2013;4(98):42-63.

25. Bothma CFC, Roodt G. The validation of the turnover intention scale SAJHRM. 2013;11(1):507-19. http://dx.doi.org/10.4102/sajhrm.v11i1.507.

26. Cotton JL, Turtle JM, Turnover E. A meta-analysis and review with implications for research. Acad Manage Rev. 1986;1986(11):55-70.

27. Hom PW, Griffeth RW. A structural equation modelling test of a turnover theory: cross sectional and longitudinal analysis. J Appl Psychol. 1991:76:350-66.

28. Tett RP, Meyer JP. Job satisfaction, organizational commitment, turnover intention and turnover: path analyses based on meta-analytic findings. Pers Psychol. 1993:46(2):259-93. http://dx.doi.org/10.1111/j.1744-6570.1993.tb00874.x.

29. Steers RM, Mowday RT. Employee Turnover and Post Decision Justification. In: Cummings LL, Staw BM, editors. Research In Organizational Behavior, 3. Greenwich, CT: JAl Press; 1981. p. 235-82.

30. Mobley WH, Horner SO, Hollingsworth AT. An evaluation of precursors of hospital employee turnover. J Appl Psychol. 1978;63(4):408-14.

31. Lambert EG, Hogan NL, Barton SM. The impact of job satisfaction on turnover intent: a test of a structural measurement model using a national sample of workers. Soc Sci J. 2001;38(2):233-50. http://dx.doi.org/10.1016/ S0362-3319(01)00110-0.

32. Blaauw D, Ditlopo P, Maseko F, Chirwa M, Mwisongo A, Bidwell P, et al. Comparing the job satisfaction and intention to leave of different categories of health workers in Tanzania, Malawi, and South Africa. Glob Health Action. 2013;6:19287. http://dx.doi.org/10.3402/gha.v6i0.19287.

33. Bonenberger $M$, Aikins $M$, Akweongo $P$, Wyss $K$. The effects of health worker motivation and job satisfaction on turnover intention in Ghana. Hum Resour Health. 2014;12:43. http://dx.doi.org/10.1186/1478-4491-12-43.

34. Alexander JA, Lichtenstein $\mathrm{R}$, Oh HJ, Ullman E. A causal model of voluntary turnover among nursing personnel in long-term psychiatric settings. Res Nurs Health. 1998:21:415-27. http://hdl.handle.net/2027.42/34677.

35. International Monetary Fund (IMF). country information, Program note-Iraq Available on: https://www.imf.org/external/np/country/notes/iraq.htm.
36. Aziz C. Struggling to rebuild Iraq's health-care system: war sanctions and mismanagement have left the health system in shambles. Lancet. 2003;362:1288-9.

37. Baylis J, Wirtz JJ, Gray CS. Strategy in the Contemporary World: An Introduction To Strategic Studies. 2nd ed. Oxford: Oxford University Press; 2007.

38. Akunjee M, Ali A. Healthcare under sanctions in Iraq: an elective experience. Med Confl Surviv. 2002;18(3):249-57. http://dx.doi.org/10.1080/ 13623690208409633.

39. Wilson J. The health care revival in Iraq. Ann Intern Med. 2004;141(10):825-8. http://dx.doi.org/10.7326/0003-4819-141-10-200411160-00027.

40. Kapp C. Anarchy pushes Iraqi health system to brink of collapse. Lancet. 2003;363:1351. http://dx.doi.org/10.1016/S0140-6736(03)13089-9.

41. Alwan NA. The killing of doctors in Iraq must stop. BMJ. 2011;343:d4467. http://dx.doi.org/10.1136/bmj.d4467.

42. Sassoon J. The Iraqi Refugees: The New Crisis in the Middle East. London: I.B. Tauris; 2009.

43. Cordesman AH, Davies ER. Iraq's Insurgency and the Road to Civil Conflict. Center for Strategic and International Studies (Washington, D.C.), Praeger Security International, Westport, United State; 2008

44. Brookings Institution and the Saban centre for Medal East policy. Tracking variables of reconstruction \& security in post-Saddam Iraq. Washington, DC; 2011. Available on: http://www.brookings.edu/ /media/Centers/ saban/iraq-index/index20120131.PDF.

45. Quinn J, Hnilicova H, Mensah E, Bencko V. Iraqi physician brain drain in prolonged conflict. N Iraqi J Med. 2011;7(1):88-98.

46. Webster PC. Iraq's health system yet to heal from ravages of war. Lancet. 2011;378(9794):863-6.

47. Webster PC. Roots of Iraq's maternal and child health crisis run deep. Lancet. 2013;831:892-4

48. Al-Khalisi N. The Iraqi medical brains drain: a cross-sectional study. Int Health Serv. 2013:43(2):363-78.

49. World Health Organization: Global Health Observatory $(\mathrm{GHO})$ data. World health statistics 2012, part III Global Health Indicators. Available on: http:// www.who.int/gho/publications/world_health_statistics/2012/en/.

50. United Nations Educational, Scientific and Cultural Organization (UNESCO). Iraq: education in transition, needs and challenges. Paris: UNESCO; 2004. Available on: http://www.unesco.org/education/iraq/na_13jan2005.pdf.

51. Alwan A. Health in Iraq, the Current Situation, Our Vision for the Future and Areas of Work. Ministry of Health, Second Edition; 2004. Available on: http:// www.who.int/hac/crises/irq/background/Iraq_Health_in_Iraq_second_ edition.pdf.

52. The World Bank. Physician per 1,000 people. Available on: http:// data.worldbank.org/indicator/SH.MED.PHYS.ZS

53. Ihsanoglu E. Assessing the human tragedy in Iraq. Int Rev Red Cross. 2007:89:915. Available on: https://www.icrc.org/eng/assets/files/other/ irrc-868_ihsanoglu.pdf.

54. Reliefweb. Iraq IDP Crisis Situation Report no. 1 (as of 4 July 2014). Available on: http://reliefweb.int/report/iraq/iraq-idp-crisis-situationreport-no-1-4-july-2014.

55. Webster PC. Iraq's growing health crisis. Lancet. 2014;384(9938):119-20. http://dx.doi.org/10.1016/S0140-6736(14)61148-X.

56. Human Rights Watch. Iraq: government attacking Fallujah hospital. Barre bombs hit residential areas. MAY 27, 2014. Available on: http:// www.hrw.org/news/2014/05/27/iraq-government-attacking-fallujah-hospital.

57. Warr P, Cook J, Wall T. Scales for the measurement of some work attitudes and aspects of psychological well-being. J Occ Psychol. 1979;52:129-48. http://dx.doi.org/10.1111/j.2044-8325.1979.tb00448.x.

58. AL Mosawi AJ. Medical education and the physician workforce of Iraq. J Contin Educ Health Prof. 2008;28(2):103-5. http://dx.doi.org/10.1002/chp.166.

59. United Nations High Commissioner for Refugees (UNHCR), the UN Refugee Agency. The internally displace people (IDPs). Available on: http:// www.unhcr.org/pages/49c3646c146.html.

60. 62. SPSS Inc. SPSS 16.0 for windows. Chicago: SPSS Inc; 2008

61. Lowell BL, Findlay A. Migration of highly skilled persons from developing countries: Impact and policy responses. International Migration Papers 44. Geneva: International Labour Office, International Migration Branch; 2001. Available on: http://www.ilo.org/public/english/protection/migrant/ download/imp/imp44.pdf.

62. Al-Dewachi O. The Professionalization of the Iraqi Medical Doctors In Britain. Ann Arbor, United States: Harvard University; 2008. 
63. Dawwas MIF, Zahare I. Testing the relationship between turnover intention and human resource practices in a non-western context of the Palestine. J Adv Soc Res. 2014;4(6):10-22.

64. Ahmad T, Riaz A. Factors affecting turn-over intentions of doctors in public sector medical colleges and hospitals. Interdiscipl J Res Bus. 2011;1(10):57-66.

65. Zhang $Y$, Feng $X$. The relationship between job satisfaction, burnout, and turnover intention among physicians from urban state-owned medical institutions in Hubei. China: a cross-sectional study. BMC Health Serv Res. 2011;11:235.

66. Heponiemi T, Kouvonen A, Virtanen M, Vänskä J, Elovainio M. The prospective effects of workplace violence on physicians' job satisfaction and turnover intentions: the buffering effect of job control. BMC Health Serv Res. 2014;14:19.

67. Mirza NM, Amjad Al, Bhatti AB, Tuz Zahra Mirza F, Shaikh KS, Kiani J, et al. Violence and abuse faced by junior physicians in the emergency department from patients and their caretakers: a nationwide study from Pakistan. J Emerg Med. 2012;42(6):727-33.

68. Camerino D1, Conway PM, Van der Heijden BI, Estryn-Behar M, Consonni D, Gould D. Low-perceived work ability, ageing and intention to leave nursing: a comparison among 10 European countries. J Adv Nurs. 2006;56(5):542-52. http://dx.doi.org/10.1111/j.1365-2648.2006.04046.x.

69. Al-Jawaheri YH. Women In Iraq: The Gender Impact of International Sanctions. London: I.B. Tauris; 2008.

70. Tai TWC, Bame SI, Robinson CD. Review of nursing turnover research, 1977-1996. Soc Sci Med. 1998;47(12):1905-24. http://dx.doi.org/10.1016/ S0277-9536(98)00333-5.

71. World Health Organization. Strengthening Nursing and Midwifery: Progress and Future Directions 1996-2000. Geneva: WHO; 1996.

72. Heponiemi T, Kouvonen A, Vanska J, Halila H, Sinervo T, Kivimaki M, et al. Effects of active on-call hours on physicians' turnover intentions and well-being. Scand J Work Environ Health. 2008;34:356-63.

73. Malik Ml, Gomez SF, Ahmad M, Saif MI. Examining the relationship of work life balance, job satisfaction and turnover in Pakistan. Int J Sustain Dev. 2010;2(1):27-33.

74. Morton M, Burnham G. Iraq's internally displaced persons: a hidden crisis. JAMA. 2008:300(6):727-9. http://dx.doi.org/10.1001/jama.300.6.727.

75. Koelewijn WT, de Rover M, Ehrenhard ML, van Harten WH. Physician entrepreneurship explained: a case study of intra-organizational dynamics in Dutch hospitals and specialty clinics. Hum Resour Health. 2014;12:28. doi:10.1186/1478-4491-12-28

76. Boerjan M, Bluyssen SJM, Bleichrodt RP, Van Weel-Baumgarten EM, Van Goo $H$. Work-related health complaints in surgical residents and the influence of social support and job-related autonomy. Med Educ. 2010;44(8):835-44.

77. Burnham G, Taylor CH, Hung YW, Ferati A, Dyer A, Hifi TA, et al. Perceptions and utilization of primary health care services in Iraq: findings from a national household survey. World Health Popul. 2012;13(3):68-79. http:// dx.doi.org/10.1186/1472-698X-11-15

\section{Submit your next manuscript to BioMed Central and take full advantage of:}

- Convenient online submission

- Thorough peer review

- No space constraints or color figure charges

- Immediate publication on acceptance

- Inclusion in PubMed, CAS, Scopus and Google Scholar

- Research which is freely available for redistribution 